\title{
O prawie medycznym i pojęciach o proweniencji medycznej w systemie prawa
}

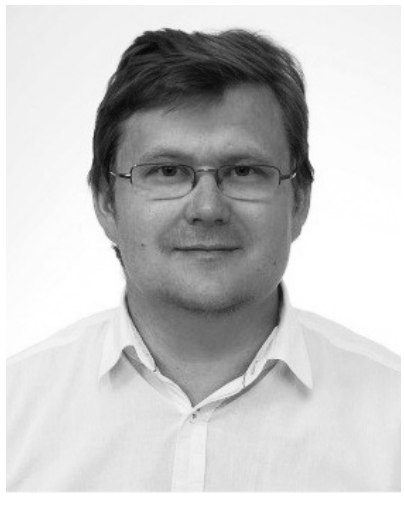

\section{Adam Górski}

Absolwent prawa na Uniwersytecie Warszawskim. Od 2016 r. profesor Uniwersytetu Jagiellońskiego. Jest również kierownikiem Zakładu Prawa Medycznego i Deontologii Lekarskiej Uniwersytetu Medycznego w Białymstoku. Zajmuje się prawem medycznym, w szczególności relacjami przepisów zawodowych lekarza i prawa karnego.

$\triangle$ adam.gorski@umb.edu.pl

https://orcid.org/oooo-0002-3403-6250

\section{On Medical Law and Medicine-Based Notions in the Law System}

\begin{abstract}
Medical law is subject to various approaches and definitions in the jurisprudence. It can be derived from the complexity of the matter, as well as its considerable novelty. Methods applied to define medical law stem from various jurisprudential convictions. This article turns attention to such basic problems of defining medical law as ratione materiae of the regulation, social structure underpinning regulation, and theoretical approaches (conceptual approach to law system, derivative concept of interpretation) to building a law system.
\end{abstract}

Słowa kluczowe: prawo medyczne, medycyna, zdrowie, system prawa

Key words: medical law, medicine, health, law system

https://doi.org/10.32082/fp.v5i55.285

\section{Uwagi wprowadzające.}

\section{Prawo i bioetyka}

Już najogólniejsze nazwy dotyczące sfery regulacyjnej tych pojęć, nie zaś tylko znaczenia samych pojęć, są tu kwestią sporną. Rodzi to podwójny problem: po pierwsze denominacji samych pojęć w przepisach prawa, po wtóre powielenia tych znaczeń w zakresie argumentacji i wykładni, w oparciu o określone znamiona systematyczności norm prawnych, jakie przychodzi stosującemu prawo odczytywać. Problem specyfiki pojęć i samego systemu prawa medycznego doczekuje się refleksji proporcjonalnej do stopnia wewnętrznej komplikacji tego, co Leszek Kubicki określił jako gałąź prawa in statu nascendi ${ }^{1}$. Paradoksalnie zaś pierwsze chyba chronologicznie rozważania teoretycznoprawne dotyczące struktury ustawodawstw zawodowych ochrony zdrowia miały miejsce na łamach periodyku związanego z ochroną zdrowia, nie zaś periodyku prawniczego ${ }^{2}$.

1 L. Kubicki, Prawo medyczne - próba ustalenia zakresu, „Prawo i Medycyna” 2000, nr 5, s. 19-26.

2 W. Patryas, Koncepcje teoretycznoprawne a akty normatywne dotyczace 
Określając, czym jest prawo medyczne, w małym stopniu zmagamy się z kwestią obowiązywania prawa. W dużym zaś stopniu sporny jest przedmiot regulacji, jej metoda, a więc i „rozczłonkowanie normatywne” źródeł prawa medycznego, które ma istotny rzeczywisty wpływ na przyjęcie i odkrycie takiej koncepcji wykładni prawa medycznego, jaka uwzględnia jego
Podstawowe pojęcia związane z normowaniem relacji próbowałem przedstawić już wcześniej ${ }^{4}$ Używa się tu takich zwrotów jak biojurysprudencja ${ }^{5}$ lub prawo medyczne, które oczywiście nie posiadają definicji ustawowej. Ostatnie zaś znajduje się w stosownym Rozporządzeniu Ministra Zdrowia z dnia 2 października 2017 r. w sprawie Lekarskiego Egzaminu Końcowego

\section{Określając, czym jest prawo medyczne, w małym} stopniu zmagamy się z kwestią obowiązywania prawa. W dużym zaś stopniu sporny jest przedmiot regulacji, jej metoda, a więc i „rozczłonkowanie normatywne” źródel prawa medycznego.

specyfikę. Wydaje się, że dla tej ostatniej kwestii znaczenie podstawowe ma zespół pojęć, które dla prawa medycznego mają charakter niezbywalny i pierwotny. Te zaś można usystematyzować, dać im określone w systemie prawa miejsce, poprzez rozważenie koncepcji konceptualistycznej (której założeniem, fundamentem wydaje się być jurysprudencja pojęć) oraz koncepcji derywacyjnej ${ }^{3}$.

stużby zdrowia, „Pielęgniarstwo Polskie” 2005, nr 2(20), s. $435-438$.

3 W najogólniejszym, jak się wydaje, sensie: M. Zieliński, Derywacyjna koncepcja wykładni jako koncepcja zintegrowana, „Ruch Prawniczy, Ekonomiczny i Socjologiczny" 2006, nr 3, s. 93-101. Zob. również w aspekcie bardziej szczegółowym B. Brożek, Derywacyjna koncepcja wykładni prawa z pespektywy logicznej, „Ruch Prawniczy, Ekonomiczny i Socjologiczny" 2006, s. 81-92; zob. także A. Choduń, Koncepcja wykładni prawa Macieja Zielińskiego, „Ruch Prawniczy, Ekonomiczny i Socjologiczny” 2006, z. 4, s. 57-67; M. Zirk-Sadowski, Problemy wyboru między konkurującymi metodami wykładni prawa, „Przegląd Prawa i Administracji” 2006, nr 103, s. 155-169. Szeroko na temat rodzajów wykładni K. Płeszka, Wykładnia rozszerzająca, Warszawa 2010. i Lekarsko-Dentystycznego Egzaminu Końcowego ${ }^{6}$, jako „zakres problematyki” i „wiedza”. Zacznijmy od terminu biojurysprudencja. Termin ten jest mocą reguły różnego znaczenia terminów określeniem o innym zakresie niż „prawo medyczne”. Oznacza on

4 A. Górski, Wykonywanie zawodu lekarza a prawo karne, Warszawa 2019, s. 19-20.

5 Począwszy od 1995 r. R. Tokarczyk, Biojurisprudenz. Eine Richtung der Jurisprudenz-Grundriss der Problematik (w:) J.C. Joerden (Hrsg.), Der Mensch und seine Behandlung in der Medizin. Bloss ein Mittel zum Zweck?, Berlin-HeidelbergNowy Jork 1999, s. 91-103; R. Tokarczyk, Biojurisprudence-le noveau courant de la jurisprudence (w:) Konstytucyjny ustrój państwa. Księga jubileuszowa profesora Wiesława Skrzydty, Lublin 2000, s. 311-324, jak również liczne publikacje tego autora podawane w: tegoż, Prawa narodzin, życia iśmierci, Warszawa 2012 i wydania wcześniejsze tej książki. Na temat pojęcia biojurysprudencji w literaturze zagranicznej por. chociażby: B. Deryck, Human Dignity in Bioethics and Biolaw, Oxford 1993, passim.

6 Dz.U. 2017 poz. 1877, s. 2.

7 W piśmiennictwie występuje także pojęcie „bioprawo”, co do niego por. chociażby R. Tokarczyk, Biojurysprudencja i bioprawo odpowiedzia na potrzeby ochrony życia w XXI wieku, „Doctrina” 2004, nr 1, s. 13-37. 
zbiór norm prawnych regulujących całość zagadnień dotyczących ochrony życia człowieka od chwili jego poczęcia aż do śmierci. Jak się wydaje, do polskiego języka prawniczego wprowadził go Roman Tokarczyk ${ }^{8}$, który wymienia biojusgenezę, biojusterapię i biojustanatologię ${ }^{9}$. Uznaje on, że biojusgeneza zajmuje się dylematami związanymi z koncepcjami prawa do życia, inżynierią genetyczną, eugeniką, sztucznym zapłodnieniem i aborcją. Biojusterapia obejmuje m.in. skomplikowane problemy transplantacji, transseksualizmu, terapii AIDS czy pewnych aspektów terapii w psychiatrii, zaś biojustanatologia stawia pytanie o kres ludzkiego życia. Dyskusję bioetyczną w prawie zgłębili natomiast w inny sposób Jerzy Stelmach, Bartosz Brożek, Marta Soniewicka i Wojciech Załuski w monografii Paradoksy bioetyki prawniczej ${ }^{10}$. Definicje lub pojęcia związane $z$ bioetyką spotykamy na kartach licznych książek i podręczników. Ben Mepham przywołuje tu definicję, według której jest to „badanie moralnych i społecznych następstw wywołanych przez technikę i płynących z postępu w naukach biologicznych"11. Autor wspomina Van Rensseleara Pottera, który określił bioetykę jako „nową dyscyplinę, która łączy w sobie wiedzę biologiczną z wiedzą o systemach ludzkich wartości, która przerzuci pomost między naukami ścisłymi i humanistycznymi, pomoże humanistyce przetrwać oraz podtrzyma i wzbogaci cywilizowany świat"12. Według krytycznych zapatrywań Tadeusza Ślipki bioetyka stanowi dział filozoficznej etyki szczegółowej, która ma ustalić oceny i normy (reguły) moralne ważne w dziedzinie działań (aktów) ludzkich, polegających na ingerencji w granicznych sytuacjach związanych z zapoczątkowaniem życia, jego trwaniem i śmiercią ${ }^{13}$. Barbara Chyrowicz rozpoczyna rozważania pojęciowe od przywołania pojęcia etyki medycznej, jakim posłużył się Thomas Persival; pod-

8 Zob. R. Tokarczyk, Prawa narodzin, życia i śmierci, Kraków 1999, s. 24.

9 Zob. również A. Górski, Wykonywanie..., dz. cyt., passim.

10 J. Stelmach i in., Paradoksy bioetyki prawniczej, Warszawa 2010 .

11 B. Mepham, Bioetyka, Warszawa 2008, s. 5.

12 Tamże.

13 T. Ślipko, Bioetyka. Najważniejsze problemy, Warszawa 2008, s. 18 . kreśla ono związek tradycyjnych wartości istotnych dla zawodu lekarza z nowymi wytycznymi odnośnie do współpracy między lekarzami ${ }^{14}$. Według Encyklopedii bioetyk $i^{15}$ jest to wyspecjalizowana część filozoficznej etyki szczegółowej, ustalająca oceny i normy moralne w stosunku do ingerencji w życie ludzkie w granicznych sytuacjach jego powstawania (biogeneza), trwania (bioterapia) i śmierci (tanatologia). Z kolei Maja Grzymkowska przywołuje ujęcie Van Rensselleara Pottera, zgodnie z którym bioetyka miałaby być nauką przetrwania, zajmującą się poszukiwaniami metody ocalenia życia całej przyrody w obliczu rozwoju techniki i cywilizacji ${ }^{16}$. Skomplikowane, mimo pozornie określonych przez prawoznawstwo relacji między różnymi systemami regulacyjnymi a systemem prawa pozytywnego, związki między etyką a prawem opisują Maria Boratyńska i Przemysław Konieczniak ${ }^{17}$. Podkreślają dyskursywność i postulatywność bioetyki, jej swoistą deklaratywność w stosunku do określoności prawa, jak również takich jego cech jak zupełność. Autorzy trafnie podkreślają też inne cechy systemu prawa, związane z koniecznością promulgacji aktu normatywnego, a więc komunikacyjne ${ }^{18}$, jako odróżniające prawo od bioetyki. Różnice te wynikają z faktu, iż są to dwa byty, systemy normatywne, co w sposób najbardziej pojemny określa normatywna teoria prawa, zaś odkrywa to już mało złożona analiza relacji norm prawnych i moralnych (choć bioetyka jest raczej nauką o normach moralnych). Konkluzję tę potwierdzałaby ocena treści najbardziej kompleksowych opracowań dotyczących etyki medycznej, ważąca antynomie i postulująca, miast normować (określać zachowania) i określać pewność. Boratyńska i Konieczniak podkreślają jednak, iż wpływ bioetyki może prowadzić do reinterpretacji niedookreślonych pojęć prawnych, niekiedy istotnie zmieniając ich treść ${ }^{19}$, co niejako

14 B. Chyrowicz, Bioetyka. Anatomia sporu, Kraków 2015, s. 16.

15 A. Muszala (red.), Encyklopedia bioetyki, Warszawa 2007, s. 63 .

16 M. Grzymkowska, Standardy bioetyczne w prawie europejskim, Warszawa 2009, s. 23.

17 M. Boratyńska, P. Konieczniak, Bioetyka a prawo (w:) J. Różyńska, W. Chańska, Bioetyka, Warszawa 2013, s. 64 i n

18 Tamże.

19 Tamże, s. 69. 
umniejsza znaczenie jurysprudencji pojęciowej (konceptualizmu prawniczego) dla prawa medycznego. Związki między prawem medycznym a bioetyką bada także Paweł Łuków, w szczególności eksponując zasady bioetyki ${ }^{20}$.

\section{Czym jest prawo medyczne?}

Również poglądy doktryny dotyczące w różny sposób prawa medycznego różnią się od siebie zasadniczo, co częściowo już przedstawiłem ${ }^{21}$, zaś w niniejszym opracowaniu poddane to zostanie rozwinięciu. Teresa Dukiet-Nagórska ${ }^{22}$ zauważa, że „[Na] prawo medyczne składa się stosunkowo duża liczba aktów prawnych, które nie są ze sobą zharmonizowane, przy czym występujące niespójności ujawniają się w obszarach o podstawowym znaczeniu zarówno dla personelu medycznego, jak i pacjentów. Z tej przyczyny nieodzowne jest podjęcie działań zmierzających do poprawy stanu rzeczy - efektem czego powinno być prawo spełniające standardy prawidłowej legislacji”. Pisze dalej, iż „w ocenie stanu prawa nie można pomijać kwestii spójności pomiędzy ustawami określającymi obowiązki personelu medycznego a ustawami określającymi uprawnienia pacjenta, bowiem te akty powinny pozostać w harmonii”. Istotne jest, że autorka tak klarownie podnosi potrzebę analizy pojęć prawa medycznego przez pryzmat prawidłowości prawodawczej. Także Rafał Kubiak ${ }^{23}$, który omawia wszystkie kryteria wyodrębniania prawa medycznego wynikające $\mathrm{z}$ nauk prawnych, w tym dogmatyki (specyfika wykładni), uznaje istnienie

20 P. Łuków, Prawo medyczne a bioetyka (w:) M. Safjan, L. Bosek (red.), System prawa medycznego, t. 1: Instytucje prawa medycznego, Warszawa 2017, s. 46-60; zob. także J. Różyńska, P. Łuków, Narodziny i natura bioetyki (w:) J. Różyńska, W. Chańska (red.), Bioetyka, Warszawa 2013, s. 15-31; T. Bechaump, J. Childress, Zasady etyki medycznej, Warszawa 1996. Kontekstowo M. Soniewicka, Selekcja genetyczna w prokreacji medycznie wspomaganej. Etyczne i prawne kryteria, Warszawa 2018

21 A. Górski, Wykonywanie..., dz. cyt., s. 20-21.

22 T. Dukiet-Nagórska, O potrzebie nowelizacji prawa medycznego, „Prawo i Medycyna” 2002, nr 11, s. 7-8.

23 R. Kubiak, Wprowadzenie do prawa medycznego (w:) E. Zielińska (red.), System prawa medycznego, t. 1: Pojęcie, źródła i zakres prawa medycznego, Warszawa 2018, s. $40 \mathrm{i} \mathrm{n.}$ gałęzi prawa, jaką jest prawo medyczne. Autor nazywa ją jednak "gałęzią kompleksową ${ }^{24}$, przy czym powołuje się na Sławomirę Wronkowską ${ }^{25}$. Uwypukla on pewne zewnętrzne cechy wskazujące na istnienie gałęzi prawa, natomiast nie nawiązuje do argumentu potrzeby regulacyjnej określonych stosunków społecznych, co wydaje się istotnym argumentem dotyczącym istnienia prawa medycznego (opartego na stosunku prawnomedycznym). Należy więc dążyć do określenia istoty stosunku prawnomedycznego, opierającego się na specyficznych relacjach społecznych, bazujących na normach konstytucyjnych, w szczególności w zakresie prawa do ochrony życia, prawa do ochrony zdrowia, zakazu eksperymentów bez uprzedniej zgody czy (nie wprost odniesionej w Konstytucji do medycyny) autonomii woli pacjenta. Komentatorzy Konstytucji, co skądinąd oczywiste, nie wskazują w swoich rozważaniach żadnej szczególnej „metody prawnomedycznej”, próbując doszukać się definicji materialnych pojęć takich jak zdrowie lub świadczenie zdrowotne ${ }^{26}$, analizując warstwę prawnomiędzynarodową problemu ${ }^{27}$, jak również związków z innymi przepisami Konstytucji. W podobny sposób ujmuje się prawo do ochrony życia (art. 38 Konstytucji RP) ${ }^{28}$ czy problem zgody na eksperyment naukowy ${ }^{29}$. Zwykle jednak prawa te są przez komentatorów mocno osadzone w koncepcji etycznej i pojęciowej, w szczególności w wypadku analizy (w tym dogmatycznej) początków życia ludzkiego oraz świadczeń zdrowotnych (zdrowia). W tym pierwszym wypadku nieodmiennie dyskutowany jest, pojęciowo właśnie, zwłaszcza status zarodka, w drugim natomiast sporne jest pozostawanie niektórych czynności medycznych, zwłaszcza aborcji,

24 Tamże, s. 38

25 S. Wronkowska, Zarys teorii prawa, Poznań 2001, s. 193.

26 L. Bosek, Komentarz. Art. 68. Prawo do ochrony zdrowia

(w:) M. Safjan, L. Bosek, Konstytucja RP, t. 1: Komentarz do art. 1-86, Warszawa 2016, s. 25.

27 Tamże.

28 T. Sroka, Art. 38. Prawo do ochrony życia (w:) M. Safjan, L. Bosek, Konstytucja RP, t. 1: Komentarz do art. 1-86, Warszawa 2016, s. 1 i n., System Legalis.

29 M. Królikowski, K. Szczucki, Art. 39. Prawo do ochrony życia (w:) M. Safjan, L. Bosek, Konstytucja RP, t. 1: Komentarz do art. 1-86, Warszawa 2016, s. 1 i n., System Legalis. 
w obrębie definicji świadczeń zdrowotnych. Jeśli jednak konstruowane są tu „definicje”, to wyłącznie w rozumieniu dogmatycznym, zaś regulacja konstytucyjna terminów medycznych jest niejako zanegowaniem jurysprudencji pojęć. Pojęcia o proweniencji medycznej charakteryzuje również z punktu widzenia komentatorów, w przeciwieństwie do niektórych rozważań na poziomie ustawowym, jednolitość interpretacyjna. Wskazuje to na wartość pojęć w procesie tworzenia się prawa medycznego, która zyskuje na znaczeniu, im bardziej jednolita i oczywista - jak w tym wypadku - jest warstwa tekstualna i legitymizacyjna rozważań. dów opieki zdrowotnej (zakładów leczniczych), a także innych podmiotów świadczących usługi medyczne. W szerszym zaś zakresie Fiutak dodaje przepisy innych gałęzi prawnych odnoszących się do wykonywania zawodów medycznych ${ }^{32}$.

W cytowanej wyżej książce Wykonywanie zawodu lekarza a prawo karne zwracałem uwagę na relacje prawa medycznego i prawa karnego wymieniając takie konwencjonalne lub doktrynalne pojęcia jak „lekarskie prawo karne”33 czy „odpowiedzialność karna lekarza” ${ }^{34}$ oraz „odpowiedzialność karna personelu medycznego" ${ }^{35}$. Termin „lekarskie prawo karne” ma słabe oparcie w języku prawnym Kodeksu karnego.

\section{W Kodeksie karnym nie ma ani jednego przestępstwa indywidualnego, którego podmiot ponad wszelką wątpliwość definiowałaby wyłącznie cecha „lekarz”.}

Należy zauważyć, iż cytowany Kubiak nie uznaje jednego sposobu wyodrębniania prawa medycznego za przeważający czy dominujący. Autor odnosi się co prawda do elementów stosunku prawnego, jednak nie wydaje się wyciągać stąd zupełnie kategorycznych konkluzji. Z kolei Zbigniew Banaszczyk ${ }^{30}$ bazuje na koncepcji zobowiązaniowego stosunku prawnego, wskazując na podmiot, przedmiot i treść stosunku zobowiązaniowego jako wyczerpujące stosunek prawnomedyczny, z czym można by polemizować z uwagi na powyższe stwierdzenie istotności kompleksu stosunków społecznych, co jest bliższe ujęciu Kubiaka ${ }^{31}$.

Dla porządku i uzupełnienia należy również przywołać opisową definicję prawa medycznego. Agnieszka Fiutak traktuje je jako zbiór przepisów prawnych regulujących prawa i obowiązki pacjenta i personelu medycznego oraz sposób funkcjonowania NFZ, zakła-

30 Z. Banaszczyk, Istota i znaczenie prywatnoprawnego stosunku medycznego (w:) M. Safjan, L. Bosek (red.), System prawa medycznego, t. 1: Instytucje prawa medycznego, Warszawa 2017, s. 321 in.

31 R. Kubiak, Wprowadzenie..., dz. cyt., s. 38 i n.
W Kodeksie karnym nie ma ani jednego przestępstwa indywidualnego, którego podmiot ponad wszelką wątpliwość definiowałaby wyłącznie cecha „lekarz”. Brak jest właściwie, wzorem niektórych innych ustawodawstw, szczególnego stypizowania przestępstw, $z$ uwagi na to, że ingerują one w procesy terapeutyczne i pojęcia bioetyczne. Krajami takimi są w pewnym zakresie Słowenia ${ }^{36}$ i Chorwacja ${ }^{37}$. Z drugiej strony nie ulega wątpliwości, że istnieją stworzone przez doktrynę i orzecznictwo pewne szczególne warunki odpowiedzialności karnej dla profesjonalistów medycz-

32 A. Fiutak, Prawo w medycynie, Warszawa 2019, s. 3 i n.

33 Zob. M. Filar, Lekarskie prawo karne, Warszawa 2000.

34 Zob. np. E. Zielińska, Odpowiedzialność zawodowa lekarza

i jej stosunek do odpowiedzialności karnej, Warszawa 2001, s. 87 i n.

35 W tej materii por. R. Kubiak, Odpowiedzialność karna za wykonywanie zabiegów kosmetycznych. Zagadnienia teorii i praktyki, Warszawa 2012; R. Kubiak, Prawo medyczne, Warszawa 2014

36 Wydaje się to wynikać z rozważań $\mathrm{D}$. Korošca, Medicinsko kazensko prawo, Lubliana 2016, s. 300 i n.

37 Informacja D. Korošca. 
nych, a ściślej i poprawniej rzecz ujmując - dla lekarzy. $\mathrm{Z}$ innej strony ten kompleks zagadnień (składający się na prawo medyczne) można trafnie definiować przedmiotowo, jak uczynił to dla prawa słoweńskiego Damjan Korošec, który po analizie definicji medycznego prawa karnego ${ }^{38}$ uznaje, iż jest to kompleks przepisów dotyczących poważnych, nieetycznych zachowań personelu medycznego popełnionych wobec pacjenta w ramach ochrony zdrowia (świadczeń zdrowotnych) i w związku z nimi ${ }^{39}$. Pozwala to oddzielić medyczne prawo karne od społecznie szkodliwych zachowań lekarza związanych z mieniem pacjenta, ubezpieczeniami czy korupcją w ochronie zdrowia. Dla tej definicji istotne jest również w dużej mierze kryterium pojęciowe relacji.

\section{Niektóre pojęcia medyczne w systemie prawa $i$ ich konstytutywny wpływ na prawo medyczne}

Stwierdzenie, że powyższe terminy, odnoszące się ogólnie do relacji pacjent - personel medyczny, są składnikiem pojęciowym właściwym gałęzi prawa (a więc założenie, że są autonomiczne), mogłoby wpłynąć również na interpretację przepisów prawa karnego dotyczących tych relacji. Są to jednak tylko ogólne ramy czy próby definiowania gałęzi (subgałęzi?) prawa. Pojęcia o proweniencji medycznej występują jednostkowo zwłaszcza jako elementy znamion przestępstw, również poprzez odesłania. Na gruncie Kodeksu karnego oprócz art. 192 pojęcie to pojawia się w art. $162 \$ 2$ i jest dookreślone przymiotnikiem „lekarski”. Paweł Daniluk $^{40}$ wymienia również takie przepisy, jak art. 74 $\$ 2$ pkt 2 k.p.k, art. 28 ust. 1 Ustawy o wychowaniu w trzeźwości i przeciwdziałaniu alkoholizmowi czy też art. 40 ust. 1, 2 i 3 Ustawy o dyscyplinie wojskowej $^{41}$. Autor ten zauważa, iż pojęcie „zabieg” obejmuje bardzo szeroki zakres czynności i podaje przykłady szeregu aktów normatywnych ${ }^{42}$.

38 D. Korošec, Medicinsko..., dz. cyt., s. 29-30.

39 Tamże, s. 30.

40 P. Daniluk, O pojęciach „zabieg leczniczy” $i$ "pacjent” w rozumieniu art. 192 k.k., „Prawo i Medycyna” 2011, nr 45 , s. $66-76$.

41 Tamże; Dz.U. 2017 poz. 2014 ze zm.

42 Referowane w A. Górski, Wykonywanie..., dz. cyt., s. 35.
Zabieg, o którym mowa w art. 192 k.k., precyzowany jest przez cel leczniczy, co z kolei powoduje konieczność wyjaśnienia pojęcia zdrowia, o czym niżej ${ }^{43}$.

Pisałem już ${ }^{44}$, że ostatnio szeroko pojęcie to omawia Iwona Wrześniewska-Wal ${ }^{45}$, nie rozstrzygając jednak jego zakresu (jak się wydaje, autorka najbliższa jest koncepcji wniknięcia w powłoki cielesne). Zwraca uwagę brak precyzji w używaniu przez ustawodawcę terminu „zabieg”. Na gruncie jednego aktu prawnego używa się np. w sposób nieprecyzyjny tego pojęcia, doprecyzowując je jako „leczniczy” oraz „lekarski”. W obu przypadkach ta differentia specifica jest nietrafna z punktu widzenia celów, jakie powinien osiągnąć ustawodawca. Można zauważyć, iż jedyną kwestią nieulegającą wątpliwości jest zawieranie się tych terminów - dowolnie rozumianych - w pojęciu świadczeń zdrowotnych.

Warto zauważyć, iż w ostatnim czasie podjęto w piśmiennictwie prawniczym bardziej systematycznie trud analizy terminów składających się - w każdym razie w języku prawniczym ${ }^{46}$ - na pojęcie leczenia, to jest profilaktyki ${ }^{47}$, diagnostyki ${ }^{48}$ czy terapii ${ }^{49}$. Jest to bardzo ważne wobec dość intuicyjnego traktowania tych pojęć w klasycznej literaturze prawniczej.

Przed nawiasem wszystkich pojęć, również wyraźnie denominowanych w systemie prawa, będzie pojęcie zdrowia.

W zakresie nauk społecznych aktualna pozostaje tendencja do szerokiego zakresowo definiowania pojęcia „zdrowie”. Taka definicja zawiera zarówno aspekt biomedyczny, jak i psychologiczny.

43 Por. P. Daniluk, Cel leczniczy w świetle poglądów doktryny i prawa, „Prawo i Medycyna” 2005, nr 1, s. 37-47.

44 A. Górski, Wykonywanie..., dz. cyt., s. 36.

45 I. Wrześniewska-Wal, Terapia (w:) E. Zielińska (red.), System prawa medycznego, dz. cyt., s. 697 i n.

46 I. Wrześniewska-Wal traktuje leczenie jako pojęcie autonomiczne w stosunku do diagnozy i terapii, por. tejże Terapia (w:) E. Zielińska (red.), System prawa medycznego, dz. cyt., s. 697 - czyni to jednak z perspektywy nauk medycznych.

47 A. Jacek, E. Sarnacka, Profilaktyka (w:) E. Zielińska (red.), System prawa medycznego, dz. cyt., s. 680-688.

48 I. Wrześniewska-Wal, Diagnostyka, diagnoza, proces diagnostyczny (w:) E. Zielińska (red.), System prawa medycznego, dz. cyt., s. 689-695.

49 I. Wrześniewska-Wal, Terapia (w:) E. Zielińska (red.), System prawa medycznego, dz. cyt., s. 696-699. 
W tym duchu utrzymana jest definicja zdrowia proponowana przez WHO. Zgodnie z tą definicją zdrowie to stan pełnego fizycznego, umysłowego i społecznego dobrostanu, a nie tylko całkowity brak choroby czy niepełnosprawności ${ }^{50}$.

Trzeba przyznać, że powyższy opis pojęcia zdrowia przemawia za derywacyjną jego interpretacją przede wszystkim przez Mirosława Nesterowicza ${ }^{53}$. Leszek Kubicki uznał je za powstającą gałąź prawa ${ }^{54}$, co stanowi główny motyw dyskusji o pojęciu prawa medycznego i co powinno oznaczać autonomizację jego pojęć i rzucać inne światło na ich znaczenie dla konstruowania norm dotyczących odpowiedzialności karnej i cywilnej lekarza czy innych zawodów medycznych ${ }^{55}$.

\section{Niewątpliwie pojęciem zbiorczym najbardziej} ugruntowanym w obszarze norm prawnych

\section{dotyczących zdrowia ludzkiego jest „prawo medyczne”.}

i, w kontekście powyższych rozważań na gruncie prawa karnego, przemawia za jak najszerszym ujęciem zdrowia na gruncie systemu prawa, jednak czynność lecznicza (dążąca w kierunku zdrowia) na gruncie prawa karnego (jako usprawiedliwiająca leczenie lub określająca jego pierwotną legalność) określana będzie przez węższe, somatyczno-psychiatryczne ujęcie, nie zaś wyłącznie pełny dobrostan psychiczny. Oznacza to, że nawet podstawowe dla prawa medycznego pojęcie nie znajduje, na gruncie definicji i określeń legalnych oraz wykładni, jednolitego znaczenia w systemie prawa.

Niewątpliwie pojęciem zbiorczym najbardziej ugruntowanym w obszarze norm prawnych dotyczących dóbr, o których tu mowa, jest wzmiankowane już co do prób definicji „prawo medyczne" ${ }^{\text {11 }}$. Mając na względzie anonosowane wyżej wątpliwości odnośnie do jego znaczenia, można roboczo spróbować określić je jako zespół norm określonych w aktach prawnych różnej rangi konstytucyjnej, ustawowej czy w aktach wykonawczych odnoszących się do tematyki ochrony zdrowia, w tym praw pacjenta ${ }^{52}$, szerzej zaś opisane zostało zakresowo

50 Tzw. dobrostan subiektywny, w tym duchu por. D. Cianciara, Zdrowie publiczne w Polsce - problemy i wyzwania, „Studia BAS” 2018, nr 4, s. 77 i n.

$51 \mathrm{Na}$ temat definicji istoty i zakresu prawa medycznego zob. cytowany już L. Kubicki, Prawo medyczne..., dz. cyt., passim.

52 J. Potulski, Prawo medyczne (w:) A. Górski (red.), Leksykon prawa medycznego, Warszawa 2012. Na temat prawa medycz-
Należy jednak podtrzymać powyższe rozważania, że różnie rozumiany jest sposób, a zwłaszcza związany z grupą (rodzajem) stosunków społecznych przedmiot regulacji prawa medycznego. Definicja (ujęcie) cywilisty Nesterowicza, podobnie jak Marka Safjana ${ }^{56}$, nie wskazuje na ograniczenie prawa medycznego do domeny prawa prywatnego. Dotyczy (zwłaszcza w wypadku wypowiedzi Safjana ${ }^{57}$ ) bardziej metaprzemiotu niż metody regulacyjnej ${ }^{58}$.

nego por. również przykładowo w literaturze polskiej: L. Kubicki (red.), Prawo medyczne, Wrocław 2003; M. Nesterowicz, Prawo medyczne, Toruń 2000 (a także wydanie z roku 2013), ponadto: J. Zajdel (red.), Meritum. Prawo medyczne, Warszawa 2016; R. Kubiak, Prawo medyczne. Wykłady specjalizacyjne, Warszawa 2010; R. Kubiak, Prawo medyczne w pytaniach i odpowiedziach, „Medycyna Praktyczna” 2014, nr 6.

53 M. Nesterowicz, Prawo medyczne, Toruń 2013.

54 L. Kubicki, Prawo medyczne..., dz. cyt., s. 20. Co do tego por. także: R. Kubiak, Wprowadzenie do prawa medycznego (w:) Pojęcie i ewolucja prawa medycznego (w:) System Prawa Medycznego, red. E. Zielińska, t. 1..., s. 40 i n.

55 Analogicznie O. Nawrot w stosunku do bioprawa, Modele wykładni funkcjonalnej bioprawa, GSP nr 2, 2010, s. 539-550.

56 M. Safjan, Zakres prawa medycznego i próba definicji, (w:) System Prawa Medycznego, tom 1. Instytucje prawa medycznego, red. M. Safjan, L. Bosek, Warszawa 2017, s. 5.

57 M. Safjan, Zakres... passim.

58 Podobnie wydaje się czynić J. Zajdel-Całkowska, która uznaje prawo medyczne za autonomiczną gałąź prawa, opartą na 
Co prawda do tego ostatniego, cywilistycznego ujęcia - ale poprzez pojęcie stosunku zobowiązaniowego zbliża się ostatnio Zbigniew Banaszczyk ${ }^{59}$, wydaje się jednak, że o differentiae specificae prawa medycznego rodzą konieczność używania różnych, często odmiennych metod interpretacji (co stanowi pewien problem dla ujęcia systemowego), jednak nie wykluczają systematyczności. Systematyka aktów prawnych nie musi

\section{Argumentacja prawnicza i wykładnia odnosi się do norm i pojęć prawnych specyficznych dla danej grupy stosunków społecznych. To one stanowią kręgosłup prawa medycznego, będąc silnie zakorzenione w Konstytucji.}

decyduje przede wszystkim metaprzedmiot normowania (przedstawiony dość dobrze przez Nesterowicza ${ }^{60}$ ), nie zaś metoda normowania ${ }^{61}$. Punktem wyjścia do normowania są przecież specyficzne regulacje, prawa i dobra konstytucyjne, które w kontekście pewnych stosunków społecznych stanowią o potrzebie reakcji prawnej ustawodawcy za pomocą różnych metod.

Pozorna „niesystematyczność” systemu prawa medycznego, jak również jego „niekodeksowość” nie są argumentem przeciwko takiemu ujęciu ${ }^{62}$. Owszem,

prawie publicznym i prywatnym; por. tejże Prawo medyczne, Warszawa 20029, s. 1

59 Z. Banaszczyk, Istota i znaczenie prywatnoprawnego stosunku medycznego, (w:) System Prawa Medycznego, tom 1. Instytucje prawa medycznego, red. M. Safjan, L. Bosek, Warszawa 2017, s. 327. Nie oznacza to, że autor nie dostrzega innych metod regulacji stosunku prawnomedycznego (przeciwnie, poprzedza swoją konkluzję wielostronną analizą), jednak ostatecznie uznaje, że „ta społeczna relacja (...) winna być regulowana za pomocą metody cywilnoprawnej”, uwypuklając, iż dominantą stosunku prawnomedycznego jest autonomia.

60 Który również gdzie indziej zauważa, że prawo medyczne łączy wspólny przedmiot i krąg adresatów, tegoż Prawo medyczne, w: Wielka encyklopedia prawa. Tom X, Warszawa 2016, s. 110.

61 Zob. również A. Górski, Wykonywanie..., s. 24

62 Zob. A. Górski, Wykonywanie..., passim. oznaczać braku kompleksowego zespołu regulacji (gałęzi), ponieważ o jej istnieniu decydują w sposób przeważający dwa argumenty: argument wspólnych pojęć (organizowany przez jurysprudencję pojęciową lub wykładnię derywacyjną) i równie silny argument tożsamych i specyficznych stosunków społecznych. To one decydują o istnieniu prawa medycznego jako (sub)gałęzi prawa.

Argumentacja prawnicza i wykładnia odnosi się do norm i pojęć prawnych specyficznych dla danej grupy stosunków społecznych. To one stanowią kręgosłup prawa medycznego, będąc - powtórzmy - silnie zakorzenione w Konstytucji6 ${ }^{3}$. Metody prawnicze (argumentacji i wykładni) stosowane w prawie medycznym nie oznaczają rezygnacji z metod charakterystycznych dla „klasycznych” gałęzi prawa, choć mogą podlegać znacznej modyfikacji, o czym pisze ostatnio zwłaszcza Kubiak ${ }^{64}$. Istotne znaczenie przy analizie pojęciowej mają w tym względzie pragmatyki i obwieszczenia, o których pisze

63 Odnośnie do Konstytucji jako źródła prawa medycznego zob. przede wszystkim L. Bosek, Źródła prawa medycznego (w:) System Prawa Medycznego, tom 1. Instytucje prawa medycznego, red. M. Safjan, L. Bosek, Warszawa 2017, s. 237 i n.; W. Brzozowski, Konstytucyjne aspekty prawa medycznego (w:) E. Zielińska (red.), System prawa medycznego, dz. cyt., s. 86-107.

64 R. Kubiak, Pojęcie i ewolucja..., dz. cyt., passim. 
Leszek Bosek ${ }^{65}$, niemające oczywiście charakteru źródeł prawa powszechnie obowiązującego. Chodzi tu zwłaszcza o „definicję” śmierci. Analizowane przez tego autora dokumenty to dobry przykład wpływu doktryny prawa na wykładnię norm prawa powszechnie obowiązującego, którymi wspomniane pragmatyki i obwieszczenia w sposób oczywisty nie są. W tym sensie trafne będzie anonsowane wcześniej spostrzeżenie Kubiaka ${ }^{66}$, iż istnieje wykładnia specyficzna dla prawa medycznego. Jest ona jednak determinowana przede wszystkim przedmiotem prawa medycznego, który czasami (choć nie scalającym elementem są prawa konstytucyjne, dla jakich pojęcia te są esencjalne. Niemałe znaczenie w reorganizacji tych pojęć ma rozumienie godności ludzkiej ${ }^{67}$. To pierwotne źródło pojęć nie oznacza jednak zawsze możliwości ich wywodzenia z systematycznych argumentów analizy prawa (argumentacji prawniczej i wykładni, np. lege non distinguente, lub wykładni funkcjonalnej czy systemowej na gruncie analizy relacji aktów normatywnych). Ładowi pojęciowemu prawa medycznego nie odpowiada bowiem pełen ład strukturalny - źródeł prawa - co konwencjo-

\section{Analiza pojęć o proweniencji medycznej} w prawie ukazuje polimorficzność znaczeniową wielu pojęć i z zasady brak ich definicji

\section{czy innych określeń legalnych.}

zawsze) bierze górę nad metodą regulacji, do momentu, do którego za użyciem wykładni specyficznej dla metody regulacji nie przemawiają względy gwarancyjne. Ma to miejsce przede wszystkim w wypadku prawa karnego, które w moim przekonaniu (w przeciwieństwie, jak się wydaje, do zapatrywania Boska) nie jest wyłączone $\mathrm{z}$ kręgu prawa medycznego.

\section{Podsumowanie}

Analiza pojęć o proweniencji medycznej w prawie wskazuje na potencjalne zjawisko polimorficzności znaczeniowej wielu pojęć i z zasady braku ich definicji i innych określeń legalnych. Nie potwierdza to intuicji, zgodnie z którą prawo medyczne jest może w pierwszym rzędzie prawem pojęć, organizowanym i scalanym przez jurysprudencję pojęciową (dla której podstawowym budulcem byłyby owe definicje). Jego

65 L. Bosek, Źródła prawa medycznego (w:) M. Safjan, L. Bosek, System prawa medycznego, t. 1: Instytucje prawa medycznego, Warszawa 2017, s. 237-314.

66 R. Kubiak, Wprowadzenie do prawa medycznego (w:) tegoż, Pojęcie i ewolucja..., dz. cyt., s. 43-44. nalnie nazwano „niekodeksowością”. Podobnie jednak jak powątpiewa się w pewne atrybuty systemu prawa ${ }^{68}$, tym bardziej założyć można, że kompleks regulacyjny zwany prawem medycznym zbudowany jest w sensie technicznolegislacyjnym na niezupełnie racjonalnej (wbrew temu podstawowemu w systemie prawa domniemaniu) strukturze normatywnej, co z punktu widzenia teoretycznego i technicznego utrudnia jego interpretację i argumentację (w tym w pewnym stopniu interpretację powyższych pojęć fundamentalnych dla prawa medycznego), jednak nie uniemożliwia jego funkcjonowania i stosowania. Istnienie tego zespołu norm, obok wymienionych tu przedmiotu regulacji i specyficznych stosunków społecznych, pomaga odczytać (ze wszelkimi jej mankamentami) derywa-

67 P. Tuleja, Stosowanie Konstytucji RP w świetle zasady jej nadrzędności (wybrane problemy), Kraków 2003, tamże jednostki i rozważania dotyczące godności ludzkiej.

68 A. Dyrda, T. Gizbert-Studnicki, Czy systemowość jest konieczna właściwościa prawa?, „Przegląd Prawa i Administracji” 2016, nr 104, wydanie specjalne (Systemowość prawa), s. 19-37. 
cyjna koncepcja wykładni prawa. Wzmiankowane wyżej pojęcia, istotne dla prawa medycznego, dadzą się zdekodować w znacznej mierze w sposób derywacyjny (w kierunku przepis prawny - norma prawna). To, że w jakimś stopniu przenosi to odczytanie znaczenia pojęć do umysłu stosującego prawo, uznać trzeba za okoliczność konieczną prawa medycznego, nie zaś przyczynek do tworzenia definicji legalnych większości pojęć związanych z medycyną.

„Pojęciowość” prawa medycznego (niebędącą jego jedyną cechą) sprawia, iż szczególne znaczenie mają w nim kwestie nazywane zarówno przez prawo, jak i bioetykę. W tym sensie i dla prawa medycznego znaczenie ma bliźniacze bioetyce pojęcie biojurysprudencji i bioprawa, jednak przedmioty tych zespołów regulacyjnych tylko w znacznej mierze się pokrywają, nie będąc tożsamymi. Wspomniano (głównie za Safjanem i Nesterowiczem), że prawo medyczne określa przedmiot regulacji (u którego fundamentów znajdują się pojęcia). Biojurysprudencja znacznie ten przedmiot i te pojęcia „zapładnia”, jako część tego samego systemu prawa, nie może być jednak z prawem medycznym utożsamiona. Dzieje się tak nie tylko ze względu na przedmiot regulacji, ale i w mniejszej mierze ze względu na konstytuujący prawo medyczne kompleks określonych i homogenicznych stosunków społecznych, leżących u jego podstaw.

Te właśnie elementy tworzą prawo medyczne jako rozwijającą się w kontekście źródeł prawa, zaś istniejącą w innych konstytuujących elementach gałąź prawa.

\section{Bibliografia}

Banaszczyk Z., Istota i znaczenie prywatnoprawnego stosunku medycznego (w:) M. Safjan, L. Bosek (red.), System prawa medycznego, t. 1: Instytucje prawa medycznego, Warszawa 2017.

Bechaump T., Childress J., Zasady etyki medycznej, Warszawa 1996.

Bosek L., Komentarz. Art. 68. Prawo do ochrony zdrowia (w:) M. Safjan, L. Bosek, Konstytucja RP, t. 1: Komentarz do art. 1-86, Warszawa 2016.

Bosek L., Źródła prawa medycznego (w:) M. Safjan, L. Bosek (red.), System prawa medycznego, t. 1: Instytucje prawa medycznego, Warszawa 2017.

Brożek B., Derywacyjna koncepcja wykładni prawa z pespektywy logicznej, „Ruch Prawniczy, Ekonomiczny i Socjologiczny" 2006, nr 3.
Brzozowski W., Konstytucyjne aspekty prawa medycznego (w:) E. Zielińska (red.), System prawa medycznego, t. 1: Pojęcie, źródła i zakres prawa medycznego, Warszawa 2018.

Cianciara D., Zdrowie publiczne w Polsce-problemy $i$ wyzwania, „Studia BAS” 2018, nr 4.

Dukiet-Nagórska T., O potrzebie nowelizacji prawa medycznego, „Prawo i Medycyna” 2002, nr 11.

Dyrda A., Gizbert-Studnicki T., Czy systemowość jest konieczną właściwościq̨ prawa?, „Przegląd Prawa i Administracji” 2016, nr 104, wydanie specjalne (Systemowość prawa).

Chyrowicz B., Bioetyka. Anatomia sporu, Kraków 2015.

Choduń A., Koncepcja wykładni prawa Macieja Zielińskiego, „Ruch Prawniczy, Ekonomiczny i Socjologiczny” 2006, nr 4.

Daniluk P., O pojęciach „zabieg leczniczy” $i$ „pacjent” $w$ rozumieniu art. 192 k.k., „Prawo i Medycyna” 2011, nr 45.

Daniluk P., Cel leczniczy w świetle poglądów doktryny i prawa, „Prawo i Medycyna” 2005, nr 1.

Filar M., Lekarskie prawo karne, Warszawa 2000.

Fiutak A., Prawo w medycynie, Warszawa 2019.

Grzymkowska M., Standardy bioetyczne w prawie europejskim, Warszawa 2009.

Górski A., Wykonywanie zawodu lekarza a prawo karne, Warszawa 2019.

Jacek A., Sarnacka E., Profilaktyka (w:) E. Zielińska (red.), System prawa medycznego, t. 1: Pojęcie, źródła i zakres prawa medycznego, Warszawa 2018.

Korosec D., Medicinsko kazensko prawo, Lubliana 2016.

Królikowski M., Szczucki K., Art. 39. Prawo do ochrony życia (w:) M. Safjan, L. Bosek, Konstytucja RP, t. 1: Komentarz do art. 1-86, Warszawa 2016, s. 1 i n., System Legalis.

Kubiak R., Odpowiedzialność karna za wykonywanie zabiegów kosmetycznych. Zagadnienia teorii i praktyki, Warszawa 2012. Kubiak R., Prawo medyczne, Warszawa 2014.

Kubiak R., Wprowadzenie do prawa medycznego (w:) E. Zielińska (red.), System prawa medycznego, t. 1: Pojęcie, źródła i zakres prawa medycznego, Warszawa 2018.

Kubicki L., Prawo medyczne - próba ustalenia zakresu, „Prawo i Medycyna” 2000, nr 5.

Mepham B., Bioetyka, Warszawa 2008.

Muszala A. (red.), Encyklopedia bioetyki, Warszawa 2007.

Nawrot O., Modele wykładni funkcjonalnej bioprawa, „Gdańskie Studia Prawnicze” 2010, nr 24.

Nesterowicz M., Prawo medyczne, Toruń 2013.

Patryas W., Koncepcje teoretycznoprawne a akty normatywne dotyczące stużby zdrowia, „Pielęgniarstwo Polskie” 2005, nr 2(20). Płeszka K., Wykładnia rozszerzająca, Warszawa 2010. 
Różyńska J., Łuków P., Narodziny i natura bioetyki (w:) J. Różyńska, W. Chańska (red.), Bioetyka, Warszawa 2013.

Safjan M., Zakres prawa medycznego i próba definicji (w:) M. Safjan, L. Bosek (red.), System prawa medycznego, t. 1: Instytucje prawa medycznego, Warszawa 2017.

Soniewicka M., Selekcja genetyczna w prokreacji medycznie wspomaganej. Etyczne i prawne kryteria, Warszawa 2018.

Stelmach J. i in., Paradoksy bioetyki prawniczej, Warszawa 2010.

Sroka T., Art. 38. Prawo do ochrony życia (w:) M. Safjan, L. Bosek, Konstytucja RP, t. 1: Komentarz do art. 1-86, Warszawa 2016, s. 1 i n., System Legalis.

Ślipko T., Bioetyka. Najważniejsze problemy, Warszawa 2008.

Tokarczyk R., Prawo ochrony człowieka, „Forum Akademickie” 1995 , nr 16.

Tokarczyk R., Biojurisprudence. New Current in Jurisprudence, „Acta Juridica Hungarica” 1995-1996, nr 1-2.

Tokarczyk R., Biojurysprudencja - nowy nurt jurysprudencji, „Nauka” 1996, nr 2.

Tokarczyk R., Biojurysprudencja - nowy nurt jurysprudencji, „Annales Universitatis Mariae Curie-Skłodowska” 1996, $\mathrm{nr}$ XLIII, section G.

Tokarczyk R., Zręby nowej jurysprudencji dla epoki nowego człowieka, „Wiadomości Uniwersyteckie” 1999, nr 2.

Tokarczyk R., Biojurisprudenz. Eine Richtung der JurisprudenzGrundriss der Problematik (w:) J.C. Joerden (Hrsg.), Der Mensch und seine Behandlung in der Medizin. Bloss ein Mittel zum Zweck?, Berlin-Heidelberg-Nowy Jork 1999.

Tokarczyk R., Biojurysprudencja eksponentem życia w juryspru dencji (w:) J.L. Krakowiak, W. Lorenc, A. Miś (red.), Filozofia, dialog, uniwersalizm. Księga dedykowana profesorowi Januszowi Kuczyńskiemu, Warszawa 2001.

Tokarczyk R., Prawa narodzin, życia i śmierci, Kraków 1999.

Tuleja P., Stosowanie Konstytucji RP w świetle zasady jej nadrzędności (wybrane problemy), Kraków 2003.

Wronkowska S., Zarys teorii prawa, Poznań 2001.

Wrześniewska-Wal I., Diagnostyka, diagnoza, proces diagnostyczny (w:) E. Zielińska (red.), System prawa medycznego, t. 1: Pojęcie, źródła i zakres prawa medycznego, Warszawa 2018.

Wrześniewska-Wal I., Terapia (w:) E. Zielińska (red.), System prawa medycznego, t. 1: Pojęcie, źródła i zakres prawa medycznego, Warszawa 2018.

Zielińska E., Odpowiedzialność zawodowa lekarza i jej stosunek do odpowiedzialności karnej, Warszawa 2001.

Zieliński M., Derywacyjna koncepcja wykładni jako koncepcja zintegrowana, „Ruch Prawniczy, Ekonomiczny i Socjologiczny” 2006, nr 3.

Zirk-Sadowski M., Problemy wyboru między konkurującymi metodami wykładni prawa, „Przegląd Prawa i Administracji" 2006, nr 103.

\section{Akty prawne}

Ustawa z dnia 9 października 2009 r. o dyscyplinie wojskowej, Dz.U. 2017 poz. 2014 ze zm.

Rozporządzenie Ministra Zdrowia z dnia 2 października 2017 r. w sprawie Lekarskiego Egzaminu Końcowego i Lekarsko-Dentystycznego Egzaminu Końcowego, Dz.U. 2017 poz. 1877. 